\title{
ADDIN
}

https://journal.iainkudus.ac.id/index.php/Addin

ISSN: 0854-0594; E-ISSN: 2476-9479

Volume 14, Number 2, August 2020: 305-328

DOI: 10.21043/addin.v14i2.7179

\section{Gender Equality and Equity with Mubadalah Concept and Its Implementation in Islamic Education}

\section{Wilis Werdiningsih}

Institut Agama Islam Negeri (IAIN) Ponorogo, Indonesia

werdiningsih@iainponorogo.ac.id

\author{
Ahmad Natsir \\ Institut Agama Islam Negeri (IAIN) Tulungagung, Indonesia \\ ennatsir@gmail.com
}

\section{Abstract}

Gender equality study is the study that will continously be discussed in human life. The study of gender examines the diverse roles of women and men in community life. The concept of mubadalah is of the new studies in gender equality. The concept of mubadalah is way of looking at two relations, namely man and woman, in which both of them as dignified human beings who are able to take advantages of all aspects of life for their good. Education is an important means of educating people who are knowledgeable and have noble character. Gender-based education is the foundation in creating a gender responsive young generation. This study aims to examine more deeply the concept of mubadalah and its implementation in Islamic education. This study used qualitative approach and the type of this research is library research. Data were obtained from various sources relate to the concept of mubadalah and Islamic education. The results show that the concept of mubadalah is one of the concepts of gender equality which can be used as a reference for understanding gender equality and equity that seeks to see women and men as servants of Allah swt. which is the subject of the texts in Al-Qur'an as well as in their interpretation. Education in an Islamic perspective becomes a forum for teaching gender equality through the design of a gender responsive education component.

Keywords: Mubadalah Concept, Gender Equality, Islamic Education. 


\section{Abstrak}

KESETARAAN GENDER, KONSEP MUBADALAH, DAN IMPLEMENTASINYA DALAM PENDIDIKAN ISLAM. Kajian kesetaraan gender menjadi kajian yang menarik untuk dibahas dalam kehidupan manusia. Gender mengkaji tentang peran perempuan dan laki-laki yang beragam dalam kehidupan masyarakat. Konsep mubadalah merupakan salah satu kajian baru dalam kesetaraan gender. Mubadalah adalah cara pandang yang melihat dua relasi, yakni laki-laki dan perempuan, di mana keduanya samasama berpikir sebagai manusia yang bermartabat untuk dapat mengambil manfaat dari segala aspek dalam kehidupan demi kebaikan keduanya. Pendidikan menjadi sarana penting dalam mendidik manusia yang berilmu dan berakhlak mulia. Pendidikan berwawasan gender menjadi fondasi dalam mencetak generasi muda yang responsif gender. Penelitian ini bertujuan mengkaji lebih mendalam tentang konsep mubadalah serta implementasinya dalam pendidikan Islam. Pendekatan yang digunakan dalam penelitian ini adalah pendekatan kualitatif dengan jenis library research. Data diperoleh dari berbagai sumber yang relevan tentang konsep mubadalah dan pendidikan Islam. Hasil menunjukkan bahwa konsep mubadalah merupakan salah satu konsep tentang kesetaraan gender yang dapat dijadikan sebagai rujukan pemahaman tentang kesetaraan dan keadilan gender yang berupaya untuk melihat perempuan dan laki-laki sebagai hamba Allah swt. yang menjadi subjek dari teks-teks dalam Al-Qur'an sekaligus dalam penafsirannya. Pendidikan dalam perspektif Islam menjadi wadah dalam mengajarkan kesetaraan gender melalui desain komponen pendidikan yang responsif gender.

Kata Kunci: Konsep Mubadalah, Kesetaraan Gender, Pendidikan Islam.

\section{A. Introduction}

Male and female are two sexes created by Allah swt. Prophet Adam a.s. as the first human being is created to be male. While the second human being created by Allah swt. to accompany the prophet Adam in heaven is Siti Eve (Hawa) who is female. Both of them lived happily in heaven for a certain period of time. Until in the end both of them were sent down to earth for violating the orders from Allah swt. From that history it can be conclude that 
God creates men and women for completing each other as Prophet Adam a.s. who live together with Siti Eve.

The sex is a God's creation, natural, immutable, nonexchangeable and applicable throughout the ages. ${ }^{1}$ No one can ask himself/herself to be born male or female. Everything happens naturally. Therefore, what can be done as a human being is to accept it with all the provisions outlined and do the best thing in life. Physically, men and women have some differences. Their reproductive organs possessed by both of them are different. So that there are primary and secondary characteristics inherent in men and women. The primary characteristic of women is the ovarium which can produce ovum, uterus and mammary glands, which are with these organs women can be pregnant, give birth and breastfeed. Whereas male's primary features can be noticed from the penis, the scrotum and testicular organs, in which those organs can produce sperm. The secondary characteristics of men are chest hair, mustache, Adam's apple which enlarges and have a voice that tends to be heavy, while women, have breasts, soft-skinned, and a high-pitched voice.

Along with the diverse life of the community, there is also a diversity of perceptions that develop with regard to the sexes of men and women. There are some societies with perceptions that that distinguish the roles of men and women along with differences in primary and secondary characteristics in both. These inherent characteristics are the reasons for the appropriateness of one sex to do something and the reason for the inconsistency of the other sex to do the same. This perception develops, varies, and changes along with the times.

The history has recorded the differences in the roles of men and women in society. It can be found some societies that truly look at women one eye, in the sense that women are the sexes that is destined to only supplement the men. The presence of women is

${ }^{1}$ Wilis Werdiningsih, "Analisis Kesetaraan Gender Pada Pembelajaran Program Keahlian Teknik Di SMK PGRI 2 Ponorogo," Kodifikasia: Jurnal Penelitian Islam 14, no. 1 (2020): 73. 
no more for the benefit of men. In the history of the Indonesian nation, there are similarities and differences between ordinary and priyayi class girls. The similarity is that both are given the freedom to play until the age of ten. And in adulthood, which is around 10-12 years, all the freedom and education enjoyed by girls ends. At that age girls begin to be prepared for family life by entering the world of seclusion. ${ }^{2}$ Seclusion is a world of women where they learn to be good housewives, by learning diversity of skills, namely cooking, sewing, ironing or learning to take care of their younger siblings. In the midst of seclusion, girls have free time which is usually spent chatting with their peers or learning to read Al-Qur'an. ${ }^{3}$

Education for girls at that time was not as much attention as boys. The education they receive is generally about religious lessons, namely learning to read Al-Qur'an. ${ }^{4}$ Both ordinary and priyayi women share this fate. Although some girls from the priyayi group receive formal education, their amount are very limited. One of the reasons is the limited of formal schools. However, the more dominant reason is because formal schools are more for men. Among the reasons from the parents not to send their daughters to school is the assumption that sending girls to school has not shown any benefits, it is not good to join boys and girls in school, girls spend more time helping with housework, sending girls to school are facing toward of tradition, girls are preferred to get married quickly, the assumption if that girls whose to school the marriage partner will be difficult, even though girls go to school she will still find difficult to get a job so that school becomes meaningless, and girls who go to school can make themselves proud of their husbands who don't go to school. ${ }^{5}$ That is why the tradition that develop in the community make girls more tied to the home environment. ${ }^{6}$

${ }^{2}$ Hamka Hasan, Tafsir Gender (Jakarta: Badan Litbang dan Diklat Departemen Agama RI, 2009), 39.

${ }^{3}$ Soekarno, Sarinah: Kewadjiban Wanita dalam Perdjoangan RI (Jakarta: Panitia Penerbit Buku Soekarno, 1963), 10.

${ }^{4}$ Hasan, Tafsir Gender, 38.

${ }^{5}$ Hasan, 38.

${ }^{6}$ R.A. Kartini, Habis Gelap Terbitlah Terang, trnsl. Armijn Pane (Jakarta: Balai Pustaka, 1978), 18-19. 
Along with the times, there have been many studies on gender. Gender equality and equity are things that must be pursued for the realization of gender relations that are take side of both sexes. Women and men are partners who have an equal position and must play a role in development and in the life of society, nation and state as well as participate in preserving religious values and Pancasila. ${ }^{7}$ Gender equality and equity are realized through access, participation, control and benefits that can be felt by women and men in community life. Mubadalah is one concept that studies about gender equality. Mubadalah is the concept of the relations between men and women as human beings who are dignified is introduced to take goodness in life. This concept is a new concept in the study of gender equality and equity. Therefore, in this study, the author wants to examine more deeply the concept of mubadalah and how it implementation in Islamic education.

This study uses a qualitative approach with a library research as its research type. The data source in this study consisted of documentary data in the form of documents related to the concept of mubadalah and the theory of Islamic education. It used is content analysis. This study aims to describe and make valid conclusions that can be reexamined. The part that is analyzed is the concept of mubadalah in the study of gender equality and its implementation in Islamic education.

The concept of mubadalah is a new concept in the study of gender equality that has not been studied by many authors. Based on the research results, the study of gender equality is more oriented to curriculum design, as well as efforts to investigate the factors behind gender inequality in people's lives, including in education. As the results of research conducted by Iswah Adriana, which reveals that the educational curriculum is still thick with a patriarchal culture. This can be seen from the teacher's factors, the learning environment, and from the textbooks. ${ }^{8}$ Furthermore,

${ }^{7}$ Supardin, “Kajian Gender Perspektif Hadis Nabi," Jurnal al-Fikr 17, no. 1 (2013): 49.

${ }^{8}$ Iswah Adriana, "Kurikulum Berbasis Gender: Membangun Pendidikan yang Berkesetaraan," Jurnal Tadris 4, no. 2 (2009): 147. 
research conducted by Rahma Fitrianti shows that gender inequality in education is influenced by factors of access, participation, control and benefits and value to education. Values and traditions that have developed in society have formed stereotypes that are damage to the women. ${ }^{9}$ In this research, we will examine in more depth the concept of mubadalah in gender equality and equity, and its implementation in Islamic education in terms of several educational components.

\section{B. Discussion}

\section{Gender and Sex}

The word "gender" comes from the English "gender". In the English-Indonesian Dictionary, gender means "sex". Whereas, in Webster's New World Dictionary, gender is defined as the apparent difference between men and women in terms of values and behavior. ${ }^{10}$ Gender is a choice of roles that can be played by men and women, which can be exchanged according to each choice. The difference between male and female is only in their reproductive organs. ${ }^{11}$ There are at least three instruments in the construction of gender, namely: First, men are considered to be masculine, with characteristics of her masculinity such as strong, mighty and brave, while women are feminine, with characteristics such as meekness, patience, and compassion. Second, men occupy the public space, while women occupy the domestic space. Third, men are in the production sector while women are in reproduction. ${ }^{12}$

In line with this explanation, Mansour Fakih explained that gender is an inherent trait of men and women who are socially and

\footnotetext{
${ }^{9}$ Habibullah and Rahma Fitrianti, "Ketidaksetaraan Gender dalam Pendidikan: Studi pada Perempuan di Kecamatan Majalaya Kabupaten Karawang," Sosiokonsepsia 17, no. 1 (2012): 89.

${ }^{10}$ Victoria Neufeldt, Webster's New World Dictionary (New York: Webster's New World Clevenland, 1984), 561.

${ }^{11}$ Iklilah Muzayyanah, A Conversation Report, Ponorogo, November 23, 2020.

${ }^{12}$ Muzayyanah.
} 
culturally constructed. ${ }^{13}$ So it can be concluded that gender is a social construction in the form of actual role choices, both men and women can choose to play it. But the communities often provide restrictions in the choice role so that it makes a bias gender construction.

Gender is not God's nature as well as sex. Gender talks about the roles that can be played by both men and women. Feminine and masculine traits can be owned by both sexed. So that the gender study concerns men and women, where the study focuses on who is the most disadvantaged from the relationship. Therefore, the most important thing is how to achieve gender equality and equity so that harmony occurs in the community lives. Both men and women can play a role in the domestic and public scope according to their respective capacities. There is no one group that is oppressed by another, and no one is suffering more than the other, the two of them complement each other to bring about goodness together.

The sex of a woman or man given by God brings physical consequences, namely differences in reproductive organs. Therefore, men and women can be clearly distinguished from their primary and secondary physical characteristics. Sex cannot be exchanged or changed and is valid for all time. The primary and secondary physical characteristics between men and women can be seen in the following table.

${ }^{13}$ Mansour Fakih, Analisis Gender dan Transformasi Sosial (Yogyakarta: Pustaka Pelajar, 2004), 8. 
Table 2.1

Primary and Secondary Physical Characteristics of Men and Women (Reproductive Organs)

\begin{tabular}{|c|c|c|}
\hline Subject & Male & Female \\
\hline Primary & $\begin{array}{l}\text { - Penis: the outer male } \\
\text { reproductive organs, as a way } \\
\text { out of urine from the body } \\
\text { through a channel called the } \\
\text { urethra. } \\
\text { - The testicles sac (skrotum): } \\
\text { temperature control system in } \\
\text { the testes. } \\
\text { - Testicles (testes): produce } \\
\text { sperm and the hormone } \\
\text { testosterone. } \\
\text { - Epididymis: store sperm cells } \\
\text { produced in the testes. } \\
\text { - Sperm. } \\
\text { - Prostate (gland) setting sperm } \\
\text { expenditure and urine/urinary } \\
\text { glands. }\end{array}$ & $\begin{array}{l}\text { - Vagina (intercourse): the birth } \\
\text { canal of the baby during childbirth } \\
\text { process and where blood is } \\
\text { released during menstruation. } \\
\text { - Uterus (uterus): place to embryos } \\
\text { for growth and development. } \\
\text { - Ovaries (ovaries): produce ovum } \\
\text { and female sex hormones, } \\
\text { estrogen, and progesterone. } \\
\text { - Ovum. } \\
\text { - Fallopian tubes: the channel for } \\
\text { the ovum moves from the ovary to } \\
\text { the uterus. } \\
\text { - Mammary gland. }\end{array}$ \\
\hline Secondary & $\begin{array}{l}\text { - Chest/hand hair. } \\
\text { - Adam's apple enlarged. } \\
\text { - Heavy voice. } \\
\text { - Mustache. }\end{array}$ & $\begin{array}{l}\text { - Smooth skin. } \\
\text { - More high-pitched sounds. } \\
\text { - Big breasts. }\end{array}$ \\
\hline
\end{tabular}

From the table of primary and secondary characteristics above, it can be known that both of primary and secondary features are naturally owned by humans through stages of human growth and development. This provision applies since the creation process of humans in ancient times. Thus it can be understood if sex is innate, natural, God's provisions and absolute. Sex is not influenced by place, time, race/ethnicity and culture so that for whatever reason it cannot change.

Furthermore, to clarify the difference between gender and sex, it can be seen in the following table. 
Table 2.2

\section{Differences Between Sex and Gender}

\begin{tabular}{ll}
\hline \multicolumn{1}{c}{ Sex } & \multicolumn{1}{c}{ Gender } \\
\hline $\begin{array}{l}\text { Cannot be changed } \\
\text { (Men and women with permanent } \\
\text { primary and secondary } \\
\text { characteristics, can not change. It is } \\
\text { in accordance with the conditions } \\
\text { of birth and develop over the time, } \\
\text { based on the stage of growth). }\end{array}$ & $\begin{array}{l}\text { May be changed } \\
\text { (The role of women and men in social life } \\
\text { in the community can change, according } \\
\text { to the development of culture in the local } \\
\text { area and influenced by the perspective of } \\
\text { the community). }\end{array}$ \\
\hline $\begin{array}{l}\text { Uninterchangeable } \\
\text { (Genders cannot be exchanged } \\
\text { with each other. Men are men. And } \\
\text { women will forever be women). }\end{array}$ & $\begin{array}{l}\text { Interchangeable } \\
\text { (The roles of women and men can be } \\
\text { exchanged according to mutual agreement). }\end{array}$ \\
\hline $\begin{array}{l}\text { Valid for whole time } \\
\text { (Sexes are permanent over the } \\
\text { time, will not be able to change or } \\
\text { be changed). }\end{array}$ & $\begin{array}{l}\text { Depends on time } \\
\text { (The role of women and men can change } \\
\text { according to the times and cultural shifts or } \\
\text { perspectives in a society). }\end{array}$ \\
\hline $\begin{array}{l}\text { Applies everywhere } \\
\text { (Wherever the sexes are the same). }\end{array}$ & $\begin{array}{l}\text { Depending on the local culture } \\
\text { (Culture somewhere affects the roles and } \\
\text { positions of men and women). }\end{array}$ \\
\hline $\begin{array}{l}\text { God's nature } \\
\text { (Born both male and female is a gift } \\
\text { from God). }\end{array}$ & $\begin{array}{l}\text { It is not God's nature } \\
\text { (God created men and women to complete } \\
\text { each other, so both of them have the same } \\
\text { position). }\end{array}$ \\
\hline $\begin{array}{l}\text { God's creation. } \\
\text { - Man-made. }\end{array}$ \\
\hline
\end{tabular}

From the table above it can be understood that there are fundamental differences between sex and gender. Sex is something natural that cannot be changed and cannot be debated, because it is something certain. While gender is a concept formed by a society that is influenced by the perspective of one group of people on gender itself. The characteristics and role of men both in domestic life and in the wider community, women always want not to be discriminated, because women have now plunged into and played a role in the sector of life. ${ }^{14}$

\footnotetext{
${ }^{14}$ Supardin, “Kajian Gender Perspektif Hadis Nabi,” 49.
} 
An understanding of the true concept of gender is fundamental because it can lead us to an understanding that both men and women have the same rights and opportunities in a society. Each of them has the right to be happy and be happied by the others. Gender differences and inequality between men and women are not caused by biological differences, but are part of the oppression of the ruling class in the production relations applied in the family concept. ${ }^{15}$ This gender inequality is the result of a dichotomous view of women and men that starts from family life.

\section{Forms of Gender Equality and Equity}

Historically, the process of human creation has been explained in Al-Qur'an. Interpretation of verses will influence the understanding of gender of men and women. When it is interpreted that Adam and Eve were created from the same type of human being, it can be understood that Adam and Hawa have the same position. However, when it is interpreted that Hawa was created from the ribs of Prophet Adam a.s., it will rise the assumption that the women are in the position of gender injustice. ${ }^{16}$

Gender equality and equity is a condition in which the cycle and portion between women and men are equal, balanced and harmonious. Women are no longer given space only to be at home and take care of the household, whereas men who are outside to work, but both men and women have the same rights and obligations to take part in domestic and public roles. A man working outside means they should not only think of their work, but also has a responsibility to think about the education of children of his. While, a woman who chooses to work outside the home, then still has to think about her responsibilities as a mother who has an obligation to educate children. Therefore, there is no gender bias. Both men and women have responsibilities in terms of children's

\footnotetext{
${ }^{15}$ Hasan, Tafsir Gender, 19.

${ }^{16}$ Adinugraha and Hendri Hermawan, "Kewenangan dan Kedudukan Perempuan dalam Perspektif Gender: Suatu Analisis Tinjauan Historis," Jurnal Marwah 7, no. 1 (2018): 56.
} 
education. Issues that need to be considered are the division of roles tailored to the capacities, situations and conditions of each.

In another hand, gender bias is favoring one sex, in social life and public policy. ${ }^{17}$ Gender bias is not only detrimental to women, but also detrimental to men. ${ }^{18}$ For example, a man is seen as a person who is strong, not whiny and mighty. So when a boy is mocked, beaten and abused, he doesn't want to look sad because of shame. He did not want to show his concern and helplessness. And this is not an easy thing. Likewise with women, the stereotypes of passive, emotional, independent women are difficult to change. Therefore if a woman wants to express her wants and needs, then she is considered irrational, selfish and aggressive. Gender bias arises in people's lives, maybe even unnoticed. In family life, society, education, mass media, and even government policies, the bias gender is still existing.

Islam is coming to bring dignity and benefit to humans, without giving priority to men or neglecting women. Women have the same authority to act as men. Azyumardi Azra said that, at the time of the Prophet Muhammad, there was no prohibition on women from being leaders. In fact Ayesha (the Prophet's wife) was once a war leader. So in the history of Muslims there are female figures who are ableto act as leaders, ulama figures, and narrators of the hadith. During the time of the Prophet, there were 1.232 women who received and narrated the hadith. Even Ummul Mukminin Aisyah r.a. listed as one of the seven treasurers of the hadith. She narrated 2.210 hadiths. Besides that Khadijah bint Khuwailid, the first wife of the Prophet, was known as a successful woman in the business world. Asy-Syifa was listed as the woman appointed by Caliph Umar as the market manager in Medina, a large market in the capital at that time. Zainab, the Prophet's wife, tanned the camels' skin and the income were offered to charity. ${ }^{19}$ So many

\footnotetext{
${ }^{17}$ Mad Sa'i, “Pendidikan Islam dan Gender," Jurnal Islamuna 2, no. 2 (2015): 124.

${ }^{18}$ Jelli Gustiana, "Bias Gender dalam Proses Pendidikan Islam," Jurnal Marwah 13, no. 1 (2014): 56 .

${ }^{19}$ Azyumardi Azra, Islam Substantif: Agar Umat Tidak Jadi Buih (Jakarta: Mizan, 2000).
} 
historical records that show successful women in their time. These historical records become evidence if women are able to make a large contribution to society, as long as the chances are given to them to show their existence.

So gender equality and equity are something that must be fought for, as Islam views the rights of men and women equally without the slightest difference. In Islam that distinguishes men and women in front of Allah swt. only their level of devotion. Both men and women have the same rights to access, benefit, play a role in the life sector in the family and community. The important thing to note, in both men and women lives is how to complement each other, complete one to other.

The form of gender equality and equity in people's lives is seen in four aspects namely access, participation, control and benefits. Access is the capacity to use resources to fully participate actively and productively (socially, economically, and politically). For example, equal opportunities for men and women in choosing education majors according to their interests and talents. Participation means taking part or taking role in every aspect of community life. Control means both women and men have the same control in the use of resources. Control is characterized by the capacity for decision making. While the benefit means that both men and women alike can benefit from the activities undertaken.

Speaking of the principles of gender awareness in an Islamic perspective, there are at least five variables that can be used, namely equality as servants of God, equality as caliphs on earth, as recipients of the same promise of divine pledge, as servants who have responsibilities and as potential servants achieve achievement. All those who are entitled to be reached by men are also entitled to be owned by women. ${ }^{20}$

${ }^{20}$ Nurdeni Dahri, “Kesadaran Gender yang Islami,” Jurnal Marwah 13, no. 2 (2014): 261. 


\section{The Concept of Mubadalah in Gender Equality and Equity}

The word mubadalah is derived from Arabic. This word comes from the ba-da-la syllable, which means to replace, change and exchange. Al-Qur'an uses this word 44 times in various forms of words with meanings around it. The word mubadalah is a form of confusion (mufa'alah) and cooperation between two parties (musyarakah) which means to replace, change, or exchange with one another.

In the modern dictionary, al-Mawrid, for Arabic-English, the work of Rohi Baalbaki, the word mubadalah means muqabalah bi al-mitsl that means confronting something with its equivalent. Then the word is translated into English with multiple meanings, namely reciprocity, reciprocation, repayment, requital, paying back, returning in kind or degree. Whereas in the Indonesian dictionary, the word "kesalingan" is used for things "that show the meaning of reciprocity".

From the some original meanings of mubadalah, then its are developed into a perspective and understanding of the particular relationship between two parties, which contains the values and spirit of partnership, the collaboration, reciprocity, and its principles. ${ }^{21}$ Relation, in this discussion, discusses various relationships that may exist in human life, namely the state and people, employers and workers, parents and children, teachers and students or the majority with a minority, between men and women, between men and men or between women and women, both on a local and global scale. But the discussion of mubadalah in relation to gender equality and equity is more interpreted by the relations that exist between men and women in the domestic and public sphere. Relationships are based on partnership and cooperation. ${ }^{22}$ Thus, the principle of mubadalah is not only reserved for those who are in pairs, but also those who establish relationships with others.

${ }^{21}$ Faqihuddin Abdul Kodir, Qira'ah Mubadalah (Yogyakarta: Ircisod, 2019), 59.

${ }^{22}$ Kodir, 244. 
However, the key of the various relationships that exist is the relationship between women and men. From the principle of partnership and cooperation, the term mubadalah is used as a method of interpretation of Islamic source texts that require men and women as an equal subjects, both of which are addressed by the text and must be included in the meaning contained in the text. In short, the simple concept of mubadalah has two meanings. The first is the relationship between partnerships between men and women and the second is how an Islamic text includes women and men as subjects of the same meaning.

In the community, there is a growing perception that only Prophet Adam a.s. which is considered as the caliph of Allah swt. on earth who carry the mandate to prosper and preserve the earth. While Hawa is not perceived as people who carry out the mandate "Caliphate" that is equal to Adam..$^{23}$ On further understanding, all men are considered as caliphs, while women are not. Yet if it refers to verses about the mandate of the Caliphate, starting from the primordial agreement on the Divine God, His humanitarian mandate, then the mandate of the Caliphate to prosper the earth and everything in it, then it refers to humans in general. One of the verses about the caliphate of man is in Q.S. al-A'raf [7]: 172 and Q.S. al-Baqarah [2]: 30. Both of these verses explain about the key of Islam, that Allah swt. creates humans by bringing primordial agreements from birth about the divinity of God and that humans were created by carrying out the mandate as caliph on earth to prosper the earth. These two verses do not use certain names (such as Prophet Adam a.s. or others) and neither mention certain sexes or certain tribes (such as the Children of Israel, Arabic or others) but in general, namely the whole human being.

Furthermore, the interpretation of the concept of the Caliphate in accordance with the key teachings of mutual help between men and women is illustrated in Q.S. at-Taubah [9]: 71. The verse above is the basic verse in the perspective of confusion.

\footnotetext{
${ }^{23}$ Kodir, 244.
} 
That verse becomes the foundation in interpreting verses about the caliphate of man on earth. That the caliphate of humans includes men and women. Therefore it is very baseless if it develops the perception of women as only halfpart of human or half part of male. So that one sex feels superior or more important than the other, while the other sex is in an inferior position. Men and women are created to complement each other, help each other out, work together for the sake of bringing goodness and distance from evil for the prosperity of God's earth as mandated as the caliphate.

Allah swt. created man and woman in the same position. The task of man is as a caliph on the earth of God to prosper. There is no difference between men and women, except in terms of their reproductive organs. In terms of worship, Islam provides various reliefs for women based on the context of the specificity of women in terms of this means of reproduction. For example for those who are pregnant, breastfeeding or menstruating. So that this relief is not in the context of assuming women are lower in status compared to men, or weaker in their faith, or more ignorant in their minds.

The principle of mubadalah is to emphasize the partnership or confusion of men and women in life. With this principle as same as the men who want to be recognized for their existence, respected by their choices, heard by their voices, and fulfilled all their desires, then women are also the same. Women also deserve to be recognized, their choices respected, and their voices heard and fulfilled. This perspective of reciprocal will produce a perspective that humanizes men and women. A perspective that leads to equal and reciprocal relations for the good of life between men and women, as capital to achieve the welfare of men and women in life in the domestic and public sphere.

The perspective of ignorance is rooted in social monotheism which emphasizes equality, equity, compassion, and respect for humanity. Like Ibn al-Qayyim al-Jauziyah, the provisions of Islamic teachings and law embody the four pillars of values, namely equity, 
wisdom, compassion, and benefit. ${ }^{24}$ The idea of the mubadalah presupposes equality and fairness in relations between men and women, and encourages the presence of participatory, equitable and beneficial cooperation between them without discrimination. The public sphere is not only intended for men, while the domestic sphere is not only charged to women. Participation in both public and domestic must be open to the widest possible extent for both men and women. In situations that are still experiencing inequality, the perspective of negligence may require men to play a greater role in the domestic realm, and open up broad space for women to take part in the public sphere. This is an effort to ensure respect for both at the same time to ensure the presence of the principle of helping each other, love each other, give opinions, be willing, treat each other well in relations between men and women.

So the perspective of reciprocity to work together is aimed as a perspective that respects the human dignity of everyone and respect for their identity. The attitude of someone who does not look at others lower than himself. An attitude of respect for others by working together to do good for one another for the common good. And in the end everyone has the right to happy.

\section{Islamic Education and Its Component Analysis}

In his book, Filsafat Pendidikan Islam: Analisis Filosofis Sistem Pendidikan Islam, Ramayulis defined Islamic education as a process of human effort that touches the whole human form, both physical and spiritual aspects. ${ }^{25}$ The mission in Islamic education is in line with the mission of Islamic teachings, namely the realization of a complete human being (insan kamil) who is physically and mentally healthy, has noble morals, and has knowledge and skills that enable him to compete in taking advantage of all available opportunities as an effort to gain happiness in life. Through Islamic education, the

\footnotetext{
${ }^{24}$ Kodir, 101.

${ }^{25}$ Ramayulis, Filsafat Pendidikan Islam: Analisis Filosofis Sistem Pendidikan Islam (Jakarta: Kalam Mulia, 2015), 121.
} 
humans who are useful for themselves and society can be realized. As well as someone who likes to practice and develop Islamic teachings in relation to Allah swt. and with fellow humans. ${ }^{26}$

In an effort to realize Islamic education, there are a number of educational components that must be considered. These components include educators, curriculum, learning approaches and methods, and evaluation. Each of these components has a role in achieving the goals of Islamic education.

Abdullah Nashih 'Ulwan said that the role of educators is to carry out scientific education, because science has a great influence on the formation of human personality. ${ }^{27}$ Educators should also provide insights on how to make human beings whole. This can be realized by making students human, maintaining their human nature, and maintaining the nature given by Allah swt. ${ }^{28}$ Thus it can be understood that educators have a big role in learning activities at school. Educators have great time and opportunity in educating students, making them a person who has a good personality and is knowledgeable and has good skills.

The curriculum contains educational planning that includes objectives, materials, methods, and evaluation. Or in another sentence, the curriculum contains what the teacher teaches to students. The curriculum determines the material that students will accept. Therefore the content of the curriculum must really be considered, so that students have the correct knowledge and understanding of science and all things. This knowledge will affect the mindset which in the end also affects the behavior of students. So that the basic things related to perspective must be taught and instilled correctly.

Regarding the learning method, Muhamad Abduh said there were five kinds of methods, namely the conceptual understanding

\footnotetext{
${ }^{26}$ Miftahul Huda, "Peran Pendidikan Islam terhadap Perubahan Sosial," Edukasia: Jurnal Penelitian Pendidikan Islam 10, no. 1 (2015): 173.

${ }^{27}$ Ramayulis, Filsafat Pendidikan Islam: Analisis Filosofis Sistem Pendidikan Islam, 228.

${ }^{28}$ Ramayulis, 228.
} 
method, the question and answer method, the practice and experience method, the exemplary method and the story method. ${ }^{29}$ Methods are an important way to choose in delivering material. Selection of the correct method that is adjusted to the material will support educators in delivering the material more easily. Therefore, the method must be really considered.

Evaluation is the final activity in a learning process. Evaluation is always preceded by an assessment activity. Assessment is intended to determine decisions related to education, whether related to planning, management, processes and follow-up education, whether involving individuals, groups or institutions. ${ }^{30}$ Evaluation depends on who did it. If an educator, then evaluation is carried out to see the success of the learning activities that have been carried out. Evaluation materials are obtained from the assessment and observation activities that have been carried out. With the evaluation, it is expected that learning activities will get better over time.

\section{Implementation of the Concept of Mubadalah in Islamic Education}

Understanding gender is an important perspective to implanted in students. This is because the perspective a person has will affect his thinking, where thoughts will encourage someone to behave as he believes. Therefore gender responsive education is important to be initiated from an early age, so that community cultures that lead to gender inequity can be eliminated. Education is the starting point for renewal. Any model of reform that is expected, including in religious matters, cannot occur without the involvement of education in it. ${ }^{31}$

\footnotetext{
${ }^{29}$ Falasipatul Asifa, "Pemikiran Pendidikan Muhammad Abduh dan Kontribusinya terhadap Pengembangan Teori Pendidikan Islam," Jurnal Pendidikan Agama Islam 15, no. 1 (2018): 95.

${ }^{30}$ Ramayulis, Filsafat Pendidikan Islam: Analisis Filosofis Sistem Pendidikan Islam, 43. ${ }^{31}$ Parisaktiana Fathonah, "Pemikiran Pendidikan Fazlur Rahman dan Kontribusinya terhadap Pengembangan Teori Pendidikan Islam," Jurnal Pendidikan Agama Islam 15, no. 1 (2018): 81.
} 
There are many gender inequity in society, it is assumed that they arise because of gender bias in education. The reality is that in education there are still many things that highlight men compared to women. ${ }^{32}$ In textbooks, there are still many things that highlight men in the public sector while women are in the domestic sector. ${ }^{33}$ This proves that the world of education is still not gender responsive and without realizing it, bias gender relations have been implanted in students from an early age.

Gender bias is a condition that favors one gender in social life and public policy. Meanwhile, gender bias in education is the reality of education that favors one particular gender, causing gender inequality. ${ }^{34}$ It takes hard efforts to eliminate all things that are gender biased which in turn can lead to gender injustice. Among the components in education that need to be considered are educators, teaching materials, methods and evaluation in learning activities. The concept of mubadalah is a perspective that can coloring gender responsive education design. The implementation of the concept of mubadalah in education is described as follows:

First, educators are education's subjects in the sense of being the first mover of learning activities. In this case, students are more passive. Students will be active or moved of students as educational subjects, because of the efforts of educators who are able to manage learning so that they do not become the main subject in learning activities. Therefore, the implementation of the concept of mubadalah in education from the educators' side, starting from the understanding of educators regarding the concept of mubadalah. So that, by understanding the concept of mubadalah, educator is able to implement it in learning activities through curriculum planning and curriculum implementation.

Second, the teaching material presented to students emphasized the principle of annoyance in partnering between men and women. In teaching, educators must describe issues related to

\footnotetext{
${ }^{32}$ Gustiana, "Bias Gender dalam Proses Pendidikan Islam," 59.

${ }^{33}$ Sa'i, "Pendidikan Islam dan Gender," 130.

${ }^{34}$ Hanun Asrohah, Sosiologi Pendidikan (Surabaya: Kopertais Press, 2018), 134.
} 
the material being taught which is often gender biased in society. So what must be done is to prepare a gender responsive Learning Implementation Plan (Rencana Pelaksanaan Pembelajaran, RPP). Educators must come up with indicators of gender responsive material and forms of gender injustice related to teaching materials. Books that feature gender-biased stories or illustrations should be explained so that students understand how to respond wisely to gender differences.

Third, in learning activities, educators plan learning activities that pay attention to gender equality in each stage of learning. For example, in the dividing of groups and the selection for presentations considering the proportion of students. So that both male and female students have the same opportunity and understand the meaning of annoyance and the principle of taking benefits for good at every stage. There is no certain gender that feels superior to others. In each given task, educators must pay attention to the roles of all male and female students.

Fourth, evaluation activities are carried out by educators to see the extent to which students understand the teaching material as well as understanding gender responsive education. Thus, through the planting of gender responsive education from an early age, the younger generation will grow into a generation capable of spreading goodness and benefit in life with the principles of gender equality and equity.

\section{Conclusion}

Gender equality and equity are something that must be applied to human life. Because through this, real peace and happiness can be realized. Every creature created by Allah swt., both male and female, has the right to gain goodness and happiness in life within the framework of getting the opportunity to choose a role in everyday life. Both men and women are equal. It is no different except only in the reproductive organs, which is nature. Besides that, it can be exchanged according to each choice. 
Gender construction in society often shows gender bias. And this is most of the time not realized. Plantings in the family, the construction of the community, the educational process are a kinds of ways for gender injustice if they are not gender responsive. Mubadalah is a concept that emphasizes resentment, partnership and good cooperation between men and women in their various relationships. That nothing is superior and nothing is inferior. The verses of Al-Qur'an as the source of Islam must be interpreted so that an Islamic text includes women and men as subjects of the same meaning.

Education becomes a forum for educators to instill gender responsive education in students. Through education, there will be young generations who have the spirit to spread kindness regardless of or favor certain genders. The education component, namely educators, curriculum, methods and evaluation are things that must be considered in initiating gender responsive education. 


\section{REFERENCES}

Adinugraha and Hendri Hermawan. "Kewenangan dan Kedudukan Perempuan Dalam Perspektif Gender: Suatu Analisis Tinjauan Historis." Jurnal Marwah 7, no. 1 (2018).

Adriana, Iswah. "Kurikulum Berbasis Gender: Membangun Pendidikan yang Berkesetaraan." Jurnal Tadris 4, no. 2 (2009).

Asifa, Falasipatul. "Pemikiran Pendidikan Muhammad Abduh dan Kontribusinya terhadap Pengembangan Teori Pendidikan Islam." Jurnal Pendidikan Agama Islam 15, no. 1 (2018).

Asrohah, Hanun. Sosiologi Pendidikan. Surabaya: Kopertais Press, 2018.

Azra, Azyumardi. Islam Substantif: Agar Umat Tidak Jadi Buih. Jakarta: Mizan, 2000.

Dahri, Nurdeni. “Kesadaran Gender yang Islami.” Jurnal Marwah 13, no. 2 (2014).

Fakih, Mansour. Analisis Gender dan Transformasi Sosial. Yogyakarta: Pustaka Pelajar, 2004.

Fathonah, Parisaktiana. "Pemikiran Pendidikan Fazlur Rahman dan Kontribusinya terhadap Pengembangan Teori Pendidikan Islam." Jurnal Pendidikan Agama Islam 15, no. 1 (2018).

Gustiana, Jelli. "Bias Gender dalam Proses Pendidikan Islam." Jurnal Marwah 13, no. 1 (2014).

Habibullah and Rahma Fitrianti. "Ketidaksetaraan Gender dalam Pendidikan: Studi pada Perempuan di Kecamatan Majalaya Kabupaten Karawang." Sosiokonsepsia 17, mo. 1 (2012).

Hasan, Hamka. Tafsir Gender. Jakarta: Badan Litbang dan Diklat Departemen Agama RI, 2009.

Huda, Miftahul. "Peran Pendidikan Islam terhadap Perubahan Sosial." Edukasia: Jurnal Penelitian Pendidikan Islam 10, no. 1 (2015).

Kartini, R.A. Habis Gelap Terbitlah Terang, trnsl. Armijn Pane. Jakarta: Balai Pustaka, 1978. 
Kodir, Faqihuddin Abdul. Qira'ah Mubadalah. Yogyakarta: Ircisod, 2019.

Neufeldt, Victoria. Webster's New World Dictionary. New York: Webster's New World Clevenland, 1984.

Ramayulis. Filsafat Pendidikan Islam: Analisis Filosofis Sistem Pendidikan Islam. Jakarta: Kalam Mulia, 2015.

Sa'i, Mad. "Pendidikan Islam dan Gender." Jurnal Islamuna 2, no. 2 (2015).

Soekarno. Sarinah: Kewadjiban Wanita dalam Perdjoangan RI. Jakarta: Panitia Penerbit Buku Soekarno, 1963.

Supardin. "Kajian Gender Perspektif Hadis Nabi." Jurnal Al-Fikr 17, no. 1 (2013).

Werdiningsih, Wilis. "Analisis Kesetaraan Gender pada Pembelajaran Program Keahlian Teknik di SMK PGRI 2 Ponorogo." Kodifikasia: Jurnal Penelitian Islam 14, no. 1 (2020). 
